DOI: $10.2478 /$ rpp-2014-0014

Doctor of Pedagogical Sciences, full professor, OLENA SEMENOG Institute of Pedagogical and Adult Education, NAPS of Ukraine Address: 9 M. Berlynskoho Str., Kyiv, 04060, Ukraine

E-mail: olenasemenog@gmail.ru

\title{
THE BEAUTY OF TEACHERS' WORK IN REFLECTIONS OF UKRAINIAN AND POLISH TEACHERS
}

\begin{abstract}
The values of human labor and teacher's work have been reflected on the basis of lexicographical sources and research reflections of famous Ukrainian and Polish pedagogues, such as T. Novatskiy, N. Nychkalo, Pope Paul II, G. Skovoroda, Z. Vyatrovskiy, I. Zyazyun. Among the existing values presented in lexicographical sources the following characteristic of the concept is chosen: "Work is the inspiration, the inner beauty of the human, spiritual richness, and self-development of a person". On the basis of literary analysis of philosophical and pedagogical works of G. Skovoroda it has been concluded that the working process was regarded by the great philosopher and educator as pleasure and happiness, in spite of the results. One can achieve this happiness following the command of inner nature due to the relationship with a certain kind of free vocational work. Pope Paul II proves that the priority function of teacher's work is educating people in love, aspiraton of Truth, Beauty, Good, Hope and Freedom, "the awakening of a human in a man". T. Novatskiy and Z. Vyatrovskiy considered teachers' work through the values of Love, Truth, Beauty, Goodness, Hope, Liberty, Justice, Solidarity. Scientists consider that teacher's work is "free", happy, optimistic and finds its true purpose only when it serves as a source of creative inspiration. The summaryzing of the publications and presentations made by N. Nychkalo proves that the teachers' work is the means of intellectual and creative potential, experience and a sense of human moral dignity.

Key words: human labor, teacher's work, values, the beauty of teachers' work, Ukrainian teachers, Polish teachers, T. Novatskiy, N. Nychkalo, Pope Paul II, G. Skovoroda, Z. Vyatrovskiy, I. Zyazyun.
\end{abstract}

\section{INTRODUCTION}

The fact that the sense of life is in work is an undeniable truth. With labor we have our health, beauty, freedom, greatness of existence, culture, morality, self-improvement, selfrealization. Pope Paul II recognized the work as one of the foundations of human existence, the basis of values' creation. Z. Vyatrovskiy considers human labor as a universal value and energy powering the whole world (Wiatrowski, 2010). "Who complains about labor, doesn't understand life", V. Yastshemskyy said (Новацький, 2010). A Polish educator and a founder of pedagogic work T. Novatskiy emphasized that only through work a person learns truth, the world; that effectiveness of existence is confirmed by human activity results and achievements. Among them are scientific and literature texts, pictures, songs, anthems, cultural improvements. The personal professional development of a person takes place when he gets results, - a Ukrainian scientist $N$. Nychkalo proves. The effectiveness of this process depends on the degree of diversity, productivity and creative nature of people's work in different social and economic sectors (Ничкало, 2011). This versatile characteristic 
can be referred to teacher's work. Any work deserves respect, and teachers' work is considered one of the most difficult and noble work in the world.

\section{THE AIM OF THE STUDY}

The article reviews the values of human labor and teachers' work basing on lexicographical sources and research reflections of the famous Ukrainian and Polish teachers T. Novatskiy, N. Nychkalo, Pope Paul II, G. Skovoroda, Z. Vyatrovskiy, I. Zyazyun.

\section{THEORETICAL FRAMEWORK AND RESEARCH METHODS}

Globalization and integration processes in the world actualize attention to research in pedagogy work and problems of teacher's work in this context. Among the Ukrainian and Polish scientists who powerfully explore this area are T. Novatskiy, N. Nychkalo, Z. Vyatrovskiy, I. Zyazyun. T. Novatskiy made a systematic, logical and phenomenological analysis of the concept of work. I. Zyazyun actively embodies the concept of pedagogical work in Ukrainian reality. N. Nychkalo performs deep interdisciplinary researches related to human labor of different ages, social and professional experience, and associated problems of professional choice, motivation, vocational training, the process of mastering the future profession, early professional activities, adaptation and peculiarities of work at different stages of professional development.

\section{RESULTS}

The word "work", as it is shown in the analysis of lexicographical sources in Ukrainian and Polish languages means: "a difficult existence, torture, burden, obligation, difficulties, troubles, feat". The summary of folklore and fiction can expand and deepen the implementation of the concept of "work" in the following meanings: "exhausted by fatigue", "difficulties", "depression", "worries", "good", "inspiration", "health", "beauty", "spiritual wealth", "inner beauty of a person", "self-development of a person".

Hard work is directly associated with well-being. It is confirmed by etymology of the lexeme "good" that means form, tableware, tools, property (Мельничук, Білодід, Коломієць \& Ткаченко, 1983). Manufacturing of basic necessities and decorations promoted the appearance of the words "profit", "advantage", "benefit", and, as a consequence, evaluation concepts of beauty, good, nobleness. People prefer work, in spite of its hardness, to laziness, because "work is good", hardworking is one of the core values that characterize a person.

The basis of these values constitutes the commandments of human values: love your relatives, don't leave your friend in trouble, perfect your Mind, Body and Soul. O. Zabuzhko represents life as work and prayers. Many sayings prove the importance of work in life (Пазяк, 1989; Stefańska-Jokiel, 2006).

Well substantiated are definitions of work, offered by Polish scientists. They are summarized by N. Nychkalo (Ничкало, 2010) and I. Zyazyun (Зязюн, 2000). In particular, S. Klonovych characterizes work as any reasonable human activity that occurs in connection with a clear influence of environmental factors and random human needs, creates the material and spiritual benefits, ensuring thereby an adequate social and economic position. T. Novatskiy in his scientific reference book "Lexicon of Work" presents the work as a form of human activity that is appropriate to the nature and is implemented according the accepted plan and the final effect. A Polish scientist F. Znanetskyy called a working man a creative creature whose identity is to make his own contributions to some deed partly under the influence of innate drive and creative instinct, partly under the influence of a society that awakens the sense of duty in a person, desire to work, awareness of the usefulness of labor and love to labor.

Natural Man (farmer) and his "akin work, namely such work to which man has a natural inclination, talent, some ability" is well described in G. Skovoroda's philosophical 
and literary works. The thinker called the soul dead if it did not find a related work, was not devoted to his natural work (Сковорода, 1995). Ideal society for G. Skovoroda was a society of workers who were experiencing the joy of creative work: “... a Bee is an emblem of a wise man, akin to working" (Сковорода, 1973).

A great philosopher regarded the process of work as pleasure and happiness, in spite of results. In the parable of "Grateful Erodiy" G. Skovoroda writes that the nature is good, the wisest, it has created everything and gives its creatures knowledge, and models of behaviors necessary for life. Teachers and doctors are helpers of nature, not its rulers. "Every work is good if it shows the way. Do not bother it, but when you can, eliminate the obstacles and make the way to it, it performs everything. Tangle itself will roll again, just take away the stone that stands in the way. Do not teach it to roll, but only help. Apple trees are not taught how to make an apple, the very nature taught it" (Сковорода, 1995).

In this context it is worth to mention Makarenko's bad pupils, who saw "the bottom" of society. They seemed not to be cleaned from dirt. But noble deeds and selfless work enabled strings to ring happily in their souls, to bring them into the mainstream of honest life.

Paul II said: "Awake a human in a man". He looked forward to establishing a deep respect for life and human dignity with the word, belief, faith, work. Pope Paul II says: "First of all the work is in fact a gift and the law of God, which is the essence of it as a subject. It is a natural property and duty, especially of adults who in their professional activity exist approximately forty years of life. It is a condition of the formation of human existence and consolidation of truthfulness" (Іван Павло II відповідає на питання Вітторіо Mесcopi, 2014). He drew attention to the role of labor in his speech on the $68^{\text {th }}$ Session of the International Labour Organisation in Geneva on June 15, 1982: "The work contains a major dimension of human existence, which is built according to the daily life from which man draws his own dignity, but which at the same time provides a certain degree of human effort, suffering and oppression and injustice which penetrate deeply into the social life of individual nations and the international community” (Іван Павло II відповідає на питання Вітторіо Meccopi, 2014).

Pope Paul II calls the work as an indispensable companion of man in his daily efforts and as a way to build the human world. A teacher in scientific studies and speeches of Pope Paul II acts as a "true friend", "helper"; his priority function is education of the working men, and the "teacher's dialogue is friendly and open". He considered teacher's profession a religious occupation, "if self-motivation is not enough, teachers' vocation will detach from the root" (Іван Павло II, 2005).

However, Pope Paul II did not take an authoritarian role of the teacher, encouraged to think about the essence of free, joyful, optimistic teacher's work over its responsibility, prudence, wisdom, spiritual depth, which aim is by its powerful experience and wisdom to promote disclosure of moral dignity, abilities to influence the moral and spiritual qualities of young people. The Holy Father called children "gift of life", "gift of God", "heaven smile", "a gift of land", "real jewels of the family and society", "hope, which always blooms again, a future that is always open" (Іван Павло II, 2005). He stressed physical and mental child labor, which the teacher must remember designing a lesson or educational classes.

The idea of "respect for the child" is riddled with a dramatic poem by Ivan Drach "Ballad of a teacher", in which the teacher stands before a "court" of world outstanding teachers J. Pestalozzi, G. Skovoroda, J. Korczak and A.Makarenko, for "everything in the world begins from the child. And in the child is the end". Adults should know - the sun comes from a baby soul.

"The hand that creates" - so Tadeusz Vaclav Novatskiy called his book, the main idea of which is the thesis that after more than five and a half million years of human and 
material life world depends mainly on manual labor, as well as strong technological systems are not able to replace human hands in many activities. I. Zyazyun uses a symbol of a hand in his book "Pedagogy of the goodness". In particular, the father's hands are "hefty, hardworking, warm and surprisingly safe, gold" and appear in the book as a symbol of good host and defense. The real university of work for the future scientists became a family in which "the culture of their ancestors and the Christian faith are kept and the rules of humane Christian ethics are strictly followed, who have the ability to survive under any hardship in life and have a great aesthetic pleasure out of life ...” (Зязюн, 2010).

Through the values of Love, Truth, Beauty, Goodness, Hope, Liberty, Justice, Solidarity labor is seen in the book of T. Novatskiy "Human labor. Analysis of the concept". The scientist proves that work is the basis of creativity, principal means of self-improvement and a prerequisite for personal fulfillment (Новацький, 2010). Only through work a man learns truthfulness, effectiveness of his existence. It is confirmed only by the results and achievements of human activities, among them are scientific and literary texts, pictures, songs, hymns, and spiritual work. For Tadeusz Novatskiy work resembles the entrance to the labyrinth, the labyrinth of knowledge with the characteristics and contexts of this type of a person's activity. "Free", happy, optimistic teacher's work is (by T. Novatskiy ) the basis of creativity, the main means of self-creation, self-improvement and personal fulfillment. $\mathrm{He}$ considers dream an important generator of psychic and spiritual energy (Новацький, 2010).

N. Nychkalo thoroughly investigates the aspects of scientific research of such Polish scientists as K. Charnetzkiy, Y. Karney, T. Novatskiy, Z. Vaytrovskiy, draws attention of scientific society to research of obligatory character of work, professional development during the whole life as well as professional qualification and competence, organization of work, conditions of qualify of professional activity, professional development of a person, justification of psyhopedagogical aspects of work. She came to conclusion that only creative work elevates and enriches a person's life and makes it truly valuable and versatile.

In humanistic society a problem of teachers who successfully master the art of axiological interaction is actualized, it affects the process of self-discovery and self-development of young citizens of Ukraine as self-sufficient and successful in the domestic and global environment. "The development of a nation is possible only if there are educated, highly spiritual, intellectual, professional teachers whose credo is pedagogical mastering", N. Nychkalo said (Ничкало, 2009). Nelly Nychkalo is guided in her life by Lina Kostenko's ideas about free and responsible work: "Relays are different. Warriors give bayonets to other warriors. Masters give their secrets to other masters" (Костенко, 2014).

Every Nelly Nychkalo's verse reminds us that life is a precious gift, a great responsibility, hard work of brain and heart, the eternal struggle between good and evil. The author emphasizes the complexity of this process and its continuity in time and space aimed at continuous and purposeful improvement of our own actions to the highest level of mastership: “... A job is not waiting. One has to do it” (Ничкало, 2012).

\section{CONCLUSIONS}

The review of the problems of pedagogical work presented in the article allows to make some conclusions. G. Skovoroda regarded the process of work as pleasure and happiness, in spite of the results. One can achieve this happiness following the command of inner nature due to the relationship with a certain kind of free vocational work. Pope Paul II proves that the priority function of teacher's work is educating people in love, aspiration of Truth, Beauty, Good, Hope and Freedom, "the awakening of a human in a man". T. Novatskiy and Z. Vyatrovskiy regarded the teacher's work through the values of Love, Truth, Beauty, 
Goodness, Hope, Liberty, Justice, Solidarity. Scientists consider that the teacher's work is "free", happy, optimistic and finds its true purpose only when it serves as a source of creative inspiration. The summaryzing of the publications and presentations made by N. Nychkalo proves that the teachers' work is the means of intellectual and creative potential, experience and a sense of human moral dignity.

\section{REFERENCES}

1. Мельничук, О. С., Білодід, І. К., Коломієць, В. Т., Ткаченко, О. Б. (1983). Етимологічний словник украӥнської мови [The etymological dictionary of the Ukrainian language]. Київ: Наукова думка (in Ukrainian).

2. Зязюн, I. (2010). Творчий доробок Тадеуша Новацького - гімн людині праці [Creative achievements of Tadeusz Novatskiy - an anthem of the working man]. In: Новацький, Т. В. Людська праця. Аналіз поняття [Human labor. Analysis of the concept]. Львів: Літопис, с. 173-176 (in Ukrainian).

3. Зязюн, I. (2000). Педагогіка добра: ідеали і реалї̈ [Pedagogy of Good: ideals and realities]. Київ: МАУП (in Ukrainian).

4. Іван Павло II відповідає на питання Bimmopio Meccopi [John Paul II answers the questions of Vittorio Messori]. Retrieved 01.03.2014 from: http://dyvensvit.org/audio/ 7884.html (in Ukrainian).

5. Іван Павло II. (2005). Пам'ять та ідентичність. Бесіди на зламі століть [Memory and Identity. Conversations at the turn of the century]. Львів: Літопис (in Ukrainian).

6. Костенко, Л. (2012). Естафети [Relays]. Retrieved 01.03.2014 from: http://poetyka. uazone.net/default/pages.phtml?place=kostenko\&page=kost12 (in Ukrainian).

7. Ничкало, Н. (2010). Ідея суспільства знань і праці в наукових пошуках [The idea of the knowledge society and labor in academic pursuits]. Теорія і практика управління соиіальними системами [Theory and practice of managing social systems], No 3, c. 22-28 (in Ukrainian).

8. Ничкало, Н. (2011). Педагогіка праці і професійна підготовка в системі педагогічних наук [Pedagogy of labour and vocational training in the system of pedagogical sciences]. In: Розвиток педагогічних наук в Украӥні $і$ Польщзі на початку XXI століття [Development of pedagogical sciences in Ukraine and Poland at the beginning of the $21^{\text {st }}$ century]. Черкаси-Київ, с. 142-152 (in Ukrainian).

9. Ничкало, Н. (2012). Учитель в образовательном пространстве: международный и украинский опыт [Teacher in the educational environment: international and Ukrainian experience]. In: Педагогическое образование в государствах-участниках СНГ: современные проблемы, концепции, теория и практика [Pedagogical education in countries participating in CIS: modern problems, concepts, theory and practice] (25-26.10.2012). Санкт-Петербург, c. $42-57$ (in Russian).

10.Ничкало, Н. (2009). Філософія освіти і педагогіка праці в науковій діяльності професора Зигмунта Вятровського [Philosophy of education and work pedagogy in scientific activities of professor Zygmunt Vyatrovskiy]. Педагогіка $i$ психологія професійної освіти [Pedagogy and psychology of professional training], No 1, c. 253-260 (in Ukrainian).

11.Ничкало, Н. (2010). Професійна педагогіка у контексті розвитку людського капіталу [Professional education in the context of human capital development]. Retrieved 01.03.2014 from: http://www.nbuv.gov.ua/portal/soc_gum/sitimn/ 2010_23/Profesiina pedagogika_u_konteksti_rozvutku.pdf (in Ukrainian). 
12.Новацький, Тадеуш В. (2010). Людська праия. Аналіз поняття [Human labor. Analysis of the concept]. Львів: Літопис (in Ukrainian).

13. Пазяк, М. М. (1989). Прислів'я та приказки: Природа. Господарська діяльність людини [Proverbs and sayings: Nature. Human activities]. Київ: Наукова думка (in Ukrainian).

14.Сковорода, Г. (1995). Пізнай в собі людину [Find out a person in yourself]. Львів: Світ (in Ukrainian).

15. Сковорода, Г. (1973). Повне зібрання творів [The Complete Works]. Київ: Дніпро (in Ukrainian).

16. Wiatrowski, Z. (2010). Praca człowieka - watpliwości, nieporozumienia i realia [Working man - doubts, misunderstandings and realities]. Stalowa Wola: Katolicki Uniwersytet Lubelski Jana Pawła II (in Polish).

17.Stefańska-Jokiel, K. (2006). Przystowia polskie [Polish Proverbs]. Wrocław: Europa (in Polish). 